Универзитет уметности у Београду, Факултет примењених уметности, Београд

DOI 10.5937/kultura1444194K

УДК 7.038.55

7.01

оригиналан научни рад

\title{
ПРОСТОРНАИНТЕРАКТИВНА
}

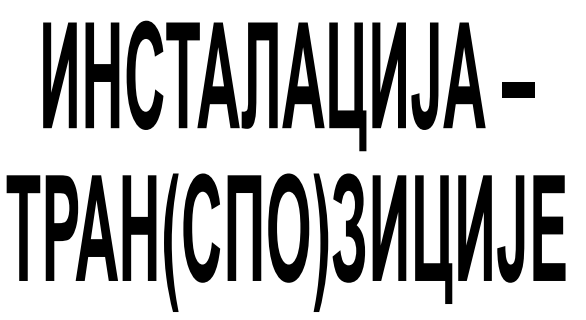

Сажетак: У тексту су предочене неке од карактеристика медија просторне интерактивне инсталације, које се могу препознати и као елементи, иначе, густе мреже неоподне за постојање интерактивног пројекта. Продукиија просторне интерактивне инсталације у разним не/комериијалним варијантама директно зависи од економске и друге моћи друштва, његовог техничко технолошког стандарда, структура културне и медијске политике, уметничких образаца, и сл. Такође, значајан је однос друштва према јавном, појединачном или заједничком деловағу. Из спреге наведених чинилаца, подједнако се отвара питање за креаторе, уметнике, и публику, учеснике, на који начин доживљавају сопствену позицију у интерактивном процесу? Тран(спо)зиције се, $u$ иначе, извесно континуирано догађају и у овој области, без обзира на то како су дефинисани , простори” наше личне или/и заједничке егзистенције.

Кључне речи: простор, инсталација, интерактивност, комуникација

$$
* * *
$$

Уметнички радови, специфично одређени простором и његовим елементима, успостављају однос са публиком, услед чега емитована енергија (у) простора(у) потврђује да „нешто као што је мртав или празан простор не постоји."

1 Шекнер, Р. Простор у амбијенталном позоришту, у: Ка Постмодерном позоришту, Између позоришта и антропологије, приредиле и превеле 


\section{БРАНКА КУЗМАНОВИЋ}

Уметничка форма у виду просторне интерактивне инсталације, заједно са осталим чиниоцима, одређује начин тумачења простора у којем се налази. Конституисана на основу односа сопствених елемената или делова, постављена је у опсегу од разређених до гушћих структура. Према Норберг - Шулцовом схватању, оне могу да се одреде као ,...домени различите 'густине”. Тако „домене са већом густином доживљавају се као 'облици', док мање густине сагледавамо као 'терене'."' Да би се физички и интелектуално упознали, домени веће густине - места, „освајају” се са више путања. Капацитет простора/места потврђује се постојањем плуралитета домена галеријског или неког другог хабитата, али и као ходолошки „простор могућих кретања”, потенцијалом за подесније путање од оних које воде „право” до циља. ${ }^{3}$

Вишеструкој екстернализацији одговара „мултисугестивност места”, која „захтева” (са)учествовање посетилаца у перцептивном организовању и нуди могућност разоткривања и артикулисања простора у функцији трагања за оним исходима, могло би се рећи у духу Велфлина, који имају „нешто несхватљиво што посматрачу унедоглед измиче". То значи отворен пут ка трансценденцији која је раније препознавана у произвођењу илузија, а сада, у најсавременијим облицима техничко технолошке продукције, као „средство зачаравања не само лиминалних домена већ свакодневног живота"5. Својим естетичким исказом, метакоментаром, као и жељом „да трансцендира материјални свет улазећи у друго царство "непростора"”, уметност се разликује од пуке инструменталне и забавне улоге.

$$
* * *
$$

Просторна интерактивна инсталација подразумева просторну организацију и артикулацију целине спољашњег или унутрашњег простора, или амбијента. Она се везује за природу

Јовићевић, А. и Вујић, И. (1992), Београд: Институт за позориште, филм, радио и телевизију, Факултет драмских уметности, стр. 17.

2 Шулц, К. Н. (2006) Егзистениија, простор и архитектура, Београд: Грађевинска књига, стр. 47.

3 Исто, стр. 39.

4 Вуксановић, Д. (2001) Барокни дух у савременој филозофији: Бењамин - Адорно-Блох, Београд: Институт за филозофију Филозофског факултетета у Београду, стр. 25.

5 Морс, М. Култура бр.107, Темат 7, Сајбер-предели, контрола и трансенденција, естетика виртуелног, 19. 07. 2014., http://www.zaprokul.org. rs/Media/Document/CasopisKultura/1712.pdf

6 Исто, http://www.zaprokul.org.rs/Media/Document/CasopisKultura/1712. pdf 


\section{БРАНКА КУЗМАНОВИЋ}

места реализације и однос посматрача према свакој врсти димензије коју може церебрално процесуирати. Инсталациja, као еклектичан медиј, има потенцијал за виртуелне, синестезијске симулације и репрезентације, и схвата физички простор као могућност за дис/континуирану дистрибуцију.

Неки видови савремене уметничке продукције су привременог карактера, а екранске слике, аудитивни и други елементи који граде мултисензорне системе јесу средства комуникације. Данас доступни и флексибилни медији могу једноставно да се пребаце у неки други и да потпуно искреирају нов контекст и смисао. Према Челанту, уметничка имагинација подразумева произвођење одређеног квалитета перцепције и простора за учешће публике, комуникација се развија експоненцијално, а виртуелно повезивање, које може бити врло неконтролисано, осећање и формативност уметности, који не подлежу више неким рестрикцијама, доводе до гашења и растапања у виртуелној реалности и до потпуне мимезе. ${ }^{8}$

Дигитално, новомедијско доба захтева и од архитектуре, да са превазилажењем линеарности и дијаграма, постави себе на нов начин. Паић сматра да би архитектура требало да буде у дигиталном простору, што значи, променити однос „спрам 'медија' своје 'медијалности', и преиначити га у 'метајезик дигиталне архитектуре'.” Место на којем се укрштају инсталација и архитектура израста на трагу виреалнога, као „....разиграно пропитивање што значи обитавати у простору виреалности кад више нема ништа 'реално' осим исконскога додира између удаљених субјеката/актера комуникације."10 Појам виреалности представљен је као 'вирус' вештачке конструкције света, са упориштем у „чистој идеји”. „Језик и слике струје у енергији чисте информације која архитектури даје потицај за сусрет с Другим."11 Из тога проистиче комуникација, не нужно интерактивна, али која даје смисао употребљеним медијима у стварању „креативне архитектонике хаоса" (Ж. Паић).

7 Морс, М. Култура бр.107, Темат 7, Сајбер-предели, контрола и трансенденција, естетика виртуелног, 19. 07. 2014., http://www.zaprokul.org. rs/Media/Document/CasopisKultura/1712.pdf

8 Челант, Ђ. (2012) Artmix, Београд: Hesperiaedu, стр. 35.

9 Паић, Ж. (2008) Нове струне технокултуре; архитектура уроњених слика, $T K X$, часопис за теорију бр. 16, Београд: Центар за теорију и праксу извођачких уметности, стр. 45.

10 Исто, стр. 44.

11 Penezić i Rogina arhitekti (2008) Tko se boji vuka još u digitalnoj eri? Interaktivna instalacija na Venecijanskom bijenalu, Zagreb: V/B/Z, str. 42. 


\section{БРАНКА КУЗМАНОВИЋ}

Питање интерактивне инсталације у архитектури дефинисано је и као одрживост идеје у току процеса реализације интерактивне инсталације као рада и догађаја. „Ријеч је, дакле, о информацији као упутству за дјеловање у интерактивној комуникацији човјека, земље, строја и оних знакова који још упућују на 'вишак имагинарнога", ${ }^{2}$ Савремена уметност и архитектура имају своје начине превођења из механичког у виртуално доба. Сам појам простора, у служби компјутерски или машински произведеног виртуелног домена, остаје невидљив, непостојећи у простору док му се не приступи и док се на неки начин материјално не визуализује, као, на пример, на дисплеју. ${ }^{13}$

$$
* * *
$$

Меклуан (Marshall McLuhan) је сматрао да су уметници они појединци, способни да у разним научним, хуманистичким и другим дисциплинама разумеју импликације нових знања у свом времену. Питао се како се носити са импликацијама будуће технологије. Уметници би могли постати пажљиви преводиоци нових уметничких форми у социјалне навигационе карте, а уметност путоказ за то како преуредити нечију психу за антиципирање наших проширених способности. ${ }^{14}$ Док је човек визуелног доба „сањао о удаљеним циљевима и о обимним енциклопедијским програмима учења," човек електронског доба „претпоставља томе дијалог и непосредно ангажовање"15. Живећи на планети као у глобалном позоришту „у којем нема гледалаца, већ само глумаца”", сви су укључени у чин стварања догађаја који је неопходно планирати или предвиђати, док само посматрати или бити „фаталан учесник", није довољно. ${ }^{17}$

Уметници су склони „развијању субјективног фактора, а избегавању сваке омеђености, попречно прелазе пространство од традиционалног до експерименталног, непрестано се бавећи метаморфозом која укључује све системе

12 Паић, Ж. (2008) Нове струне технокултуре; архитектура уроњених слика, TKX, часопис за теорију бр. 16, Београд: Центар за теорију и праксу извођачких уметности, стр. 44.

13 Морс, М. Култура бр.107, Темат 7, Сајбер-предели, контрола и трансенденција, естетика виртуелног, 19. 07. 2014., http://www.zaprokul.org. rs/Media/Document/CasopisKultura/1712.pdf

14 Ran, F. (2009) A History of Installation Art and the Development of New Art Forms, New York: Peter Lang, стр. 211.

15 Маклуан, М., Свет као глобално позориште, 10. 07. 2014., www.zaprokul. org.rs/Media/Document/CasopisKultura/784.pdf.

16 Исто, www.zaprokul.org.rs/Media/Document/CasopisKultura/784.pdf.

17 Исто, www.zaprokul.org.rs/Media/Document/CasopisKultura/784.pdf. 


\section{БРАНКА КУЗМАНОВИЋ}

комуникације” 18 . Систем је изгубио своју „хијерархијску стабилност" (Ђ. Челант), у којем, услед поништавања традиционалних разлика и категорија „настају вишеструке и фрагментарне формације"19, и већ, скоро свуда, присутна интерактивност као друштвено пожељан облик деловања. Тако, и савремену уметничку праксу прати исти принцип, који у контексту мултимедијалности, добија нов квалитет.

$* * *$

У конструисаном свету просторно - временских датости инсталације, и уметник и посетилац користе информације чинећи то готово увек из свог центра. ${ }^{20}$ Интерреагујући на граници очекиваног и изненађена, одређен степен „модалитета личности" (М. Морс) посматрача, тражи своју референтну тачку у односу према простору, најпре, на основу инстинктивног осећања. Мноштво „веза између простора, у телу са просторима у којима се тело налази"21, ствара простор „конституисан према пољима личне енергије”22, који из спољашње физичке манифестације почиње да се претапа ка унутрашњој. Комуникација са простором се одржава „,.. путем напона између наше непосредне ситуације као егзистенције конкретног простора и простора егзистенције”23, у којој се сучељавају идентитети разних субјеката свих фаза рада у колоплету различитих искустава.

У просторној интерактивној инсталацији појављује се „дистрибуирано ауторство над садржајем."24 На основу добро повезане структуре за стварање садржаја рада,

18 Челант, Ђ. (2012) Artmix, Београд: Hesperiaedu, стр. 13.

19 Исто, стр. 22.

20 „Постајете свесни свог тела као система запремина, делова и ритмова: као усклађене збирке просторија, канала, чврсте, флуидне и гасовите материје: као комбинације еластичних, крутих костију које су прекривене и повезане гипким, растегљивим мишићима и мембранама - све ово подржава и окружује централне, пулсирајуће, животне увале, заливе, и групе покретне унутрашњости"; Шекнер, Р. Простор у амбијенталном позоришту, у: Ка Постмодерном позоришту, Између позоришта и антропологије, приредиле и превеле Јовићевић, А. и Вујић, И. (1992), Београд: Институт за позориште, филм, радио и телевизију, Факултет драмских уметности, стр. 21.

21 Исто, стр. 21.

22 Исто, стр. 18.

23 Шулц, К. Н. (2006) Егзистенщија, простор и архитектура, Београд: Грађевинска књига, стр. 61.

24 Клеут, J. (2012), Култура бр. 135, Интерактивност и мултимедијалност у потрази за значењем и континуитетом, Београд: Завод за проучванње културног развика, стр. 166. 


\section{БРАНКА КУЗМАНОВИЋ}

развија се однос „корисника према генерисању садржаја.”25 А у хипостазираним амбијентима (Д. Вуксановић), ${ }^{26}$ фокус се пребацује са аутора на публику и подржава идеју да публика има/добије замисао да буде „главни редитељ”.Укључивањем у разне врсте испитивања учесници остварују неку врсту хипнагогичке „визије” креирањем сопственог доживљаја, што доприноси њиховом осећају компактности/ хармоније са радом.

„Који утисак на посматрача оставља калеидоскоп ендогених тачки посматрања и напетост између физичког и апстрактног доживљаја?"27

Адекватно одабраним путевима „установљава се присутност" посетилаца, долази до међусобног сусретања учесника и уметника, до новонасталог искуства које често директно зависи од вештина индивидуе да се активно укључи у креирање. Ново искуство утврђује се смером комуницирања, учесталошћу интеракција, количином избора, респонсивношћу система, степеном корисничке контроле, могућношћу корисника да мења форму или садржај поруке, чулним богатством и евентуално, осећајем телеприсуства. ${ }^{28}$

Потпуно „уроњено” тело у интерактивно окружење и тоталитет, ограничено је у свом деловању, иако се појединац осећа комплетним и сигурним у ситуацији коју сматра реалном. Он нема осећај да је укључен у технолошку конструкцију просторно темпоралне симулације. ${ }^{29}$ У још радикалнијој техничко технолошкој тенденцији да у наш мозак буде уграђен чип којим се директно комуницира (интерфејсом између људског нервног система и компјутера - wireheading), омогућено је интелигентно складиштење интеракције у меморију, могућност евоцирања успомена, презентовање искустава, контролисање и мењање времена, прошлости, садашњости и будућности. ${ }^{30} \mathrm{C}$ једне стране, нивои интерперсоналне размене се померају са микро плана ка интраперсоналној комуникацији и идеји о сопственој слободи.

\footnotetext{
25 Исто, стр. 166.

26 Вуксановић, Д. Уметничко стваралаштво као медијум потрошње, у Теорија уметничког стварања: зборник радова, уредници Грубор, Н. иЈанковић, С. (2007) Панчево, Београд: Мали Немо,Естетичко друштво Србије, стр. 193.

27 Грау, О. (2008) Виртуелна уметност, Београд: Clio, стр.18.

28 Клеут, Ј. (2012) Интерактивност и мултимедијалност у потрази за значењем и континуитетом, Култура бр. 135, Београд: Завод за проучавање културног развитка, стр. 166-171.

29 Ran, F. (2009) A History of Installation Art and the Development of New Art Forms, New York: Peter Lang, стр. 204.

30 Исто, стр. 205.
} 


\section{БРАНКА КУЗМАНОВИЋ}

\section{$* * *$}

Уколико се људска усамљеност програмски обликује тако да се људи усмеравају једни на друге, можда ће ти „разговори усамљеника" бити ипак у конверзацији мноштва, без јасне границе утицаја спољашњег или унутрашњег фактора, али са свепрожимајућим утицајима. На овај начин, исказује се жеља за „друштвеним приближавањем обнови заједница, јер је ту у питању начело урушавања вредности које чине заједнички говор и суд." ${ }^{\prime 1}$ Нестајањем комуникацијских интерфејских баријера могуће је транспарентност комуникације учинити непосреднијим искуством мноштва у којој би се изгубиле позиције учесника-креатора и учесника-посматрача и која би се спонтано уређивала флуидном енергијом масе. Померање из „затвореног система комуникације” у „отворени систем" носи ризик да, уколико је читав догађај подигнут на ниво спектакла, рад постане готово невидљив, а сама интеракција његов декор.

Разматрајући питања у вези са учешћем субјекта у савременој пракси и ефектима наметања публици, Крајнак сматра да, ангажовање публике често делује „као некаква бенигна инклузивна естетика." 32 Институције које промовишу партиципацију кроз отворен демократичан систем учешћа, долазе у ситуацију да можда и не знајући, тиме прекривају више ствари. Између осталог, у случају када настоје да савремену уметност учине „мање мистериозном и пријатнијом." ${ }^{\prime 3}$ „...потенцијално дестабилизујући ефекти учешћа претварају се у доктрину лако доступног уметничког погледа" 34 . Посматрач је стављен у позицију хедонисте, без обавезе да заиста разуме, а „уметник више није произвођач, већ пажљиви чувар и хранилац који обезбеђује опстанак, забаву и друге врсте уживања, публици ..." 35

31 Арден, П. (2007) Контекстуална уметност, Нови Сад: Музеј савремене уметности Војводине, стр. 224.

32 Крајнак, Џ. Зависно учешће: амбијенти Бруса Наумана (Brusa Naumana) у: Слика/покрет/трансформација покретне слике у уметности, приредили Чекић, Ј. и Станковић, М. (2013), Београд: Центар за медије и комуникације, Факултет за медије и комуникације, Универзитет Сингидунум, стр. 189.

33 Исто, стр. 189.

34 Исто, стр. 190.

35 Исто, стр. 190. 


\section{БРАНКА КУЗМАНОВИЋ}

\section{ЛИТЕРАТУРА:}

Арден, П. (2007) Контекстуална уметност, Музеј савремене уметности Војводине, Нови Сад.

Вуксановић, Д. (2001) Барокни дух у савременој филозофији: Бенамин - Адорно-Блох, Београд: Институт за филозофију Филозофског факултета у Београду.

Челант, Ђ. (2012) Artmix, Hesperiaedu, Београд.

Грау, О. (2008) Виртуелна уметност, Clio, Београд.

Клеут, J. (2012) Интерактивност и мултимедијалност у потрази за значењем и континуитетом, Култура бр. 135, Београд: Завод за проучавање културног развитка.

Маклуан, М. Свет као глобално позориште, 10. 07. 2014., www. zaprokul.org.rs/Media/Document/CasopisKultura/784.pdf

Морс, М. Темат 7, Сајбер-предели, контрола и трансенденција, естетика виртуелног, Култура бр. 107, 19. 07. 2014., http://www. zaprokul.org.rs/Media/Document/CasopisKultura/1712.pdf.

Паић, Ж. (2008) Нове струне технокултуре; архитектура уроњених слика, TKX, часопис за теорију бр. 16, Београд: Центар за теорију и праксу извођачких уметности.

Penezić i Rogina arhitekti, (2008) Tko se boji vuka još u digitalnoj eri? Interaktivna instalacija na Venecijanskom bijenalu, Zagreb: $\mathrm{V} / \mathrm{B} / \mathrm{Z}$.

Ка постмодерном позоришту, Између позоришта и антропологије, приредиле и превеле Јовићевић, А. и Вујић, И. (1992), Београд: Факултет драмских уметности, Институт за позориште, филм, радио и телевизију.

Ran, F. (2009) A History of Installation Art and the Development of New Art Forms, Peter Lang, New York.

Чекић, Ј. и Станковић, М. (прир.) (2013)Слика/покрет/трансформација покретне слике у уметности, Београд: Универзитет Сингидунум, Факултет за медије и комуникације, Центар за медије и комуникације.

Грубор, Н., Јанковић, С. (ур.) (2007) Теорија уметничког стварања: зборник радова, Београд: Естетичко друштво Србије; Панчево: Мали Немо.

Шулц, К. Н. (2006) Егзистенција, простор и архитектура, Београд: Грађевинска књига 
БРАНКА КУЗМАНОВИЋ

\title{
Branka Kuzmanović \\ University of Arts in Belgrade, Faculty of Applied Arts, Belgrade \\ SPACE INTERACTIVE INSTALLATION - TRAN(SPO)SITIONS
}

\begin{abstract}
This text presents some of the characteristics of space interactive installation, which can be recognized as elements of otherwise dense networks necessary for the existence of an interactive project. Production of spatial interactive installations in various non/commercial versions directly depends on the economic and other strenghts of the society, its technical and technological standards, structures of cultural and media policy, artistical patterns, etc. The attitude of the society towards a public, individual or joint action is also important. Interaction of these factors gives rise to a question for the creators, artists, audiences and participants as to how they perceive their position in the interactive process. Tran(spo)sitions will occur anyway in this area, regardless of how are defined "spaces" of our personal and/or shared existence.
\end{abstract}

Key words: space, installation, interactivity, communication

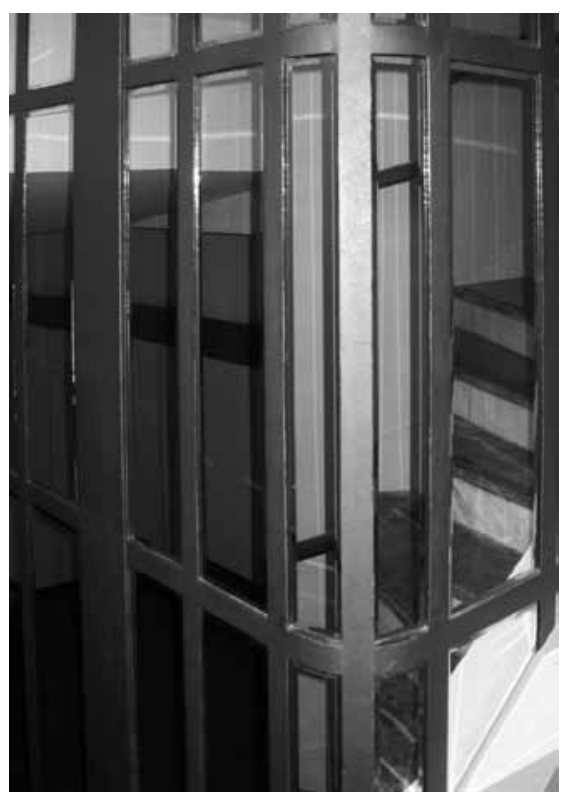

Хотел Excelsior, Београд, 2007, фото Мариела Цветић 